\title{
WHY THEY PERSIST? AN ANALYSIS OF DUAL CLASS STRUCTURES AND THE UNIFICATION PROCESS INTHE U.S. AND BRAZIL*
}

Gabriela M. Engler Pinto

POR QUE ELAS RESISTEM? ANÁLISE DAS ESTRUTURAS "DUAS CLASSES" DE CAPITAL E O PROCESSO DE UNIFICACÃO NOS EUA E NO BRASIL

\section{RESUMO}

A SEPARAÇÃO ENTRE DIREITOS ECONÔMICOS E POLITICOS TEM SIDO SEVERAMENTE CRITICADA EM TODO O MUNDO. AINDA ASSIM, ESTRUTURAS DE CAPITAL QUE DIVERGEM DO PARADIGMA "UMA AÇÃO, UM VOTO" PERSISTEM COMO UMA ALTERNATIVA AMPLAMENTE ADOTADA. ESTE ARTIGO BUSCA OFERECER ALGUMAS EXPLICAÇÕES SOBRE PORQUE ISSO ACONTECE, A PARTIR DE UMA PERSPECTIVA COMPARATIVA QUE ANALISA OS CONTEXTOS DO BRASIL E DOS EUA, DOIS PAÍSES QUE TÊM UMA ABORDAGEM BASTANTE DIFERENTE EM RELAÇÃO ÀS ESTRUTURAS DE CONTROLE ACIONÁRIO. PARA TANTO, ANALISA-SE AS ESTRUTURAS DE CONTROLE QUE CONTEMPLAM MAIS DE UMA CLASSE DE AÇÕES, SUAS PRINCIPAIS CARACTERÍSTICAS E O PROCESSO DE UNIFICAÇÃO VERIFICADO NOS DOIS PAÍSES. A PARTIR DESSAS DISCUSSÕES, O ARTIGO APRESENTA ARGUMENTOS PARA EXPLICAR PORQUE A ESTRUTURA DE CONTROLE COM MAIS DE UMA CLASSE DE AÇ̃̃ES AINDA PERSISTE NO BRASIL E NOS EUA (EMBORA COM INTENSIDADE VARIÁVEL), APESAR DE TODAS AS CRÍTICAS SOBRE A SEGREGAÇÃO ENTRE DIREITOS ECONÔMICOS E POLÍTICOS.

\section{PALAVRAS-CHAVE}

DUAS CLASSES DE AÇÕES; UNIFICAÇÃO; CONTROLE ACIONÁRIO; UMA AÇÃO UM VOTO.

\section{ABSTRACT}

THE UNBUNDLING OF CASH FLOW AND VOTING RIGHTS HAS BEEN SEVERELY CRITICIZED WORLDWIDE AND YET, THE DUAL CLASS STRUCTURE PERSISTS AS AN ALTERNATIVE WIDELY ADOPTED BY FIRMS. THIS PAPER AIMS TO PROVIDE SOME EXPLANATIONS AS TO WHY THIS HAPPENS, PARTICULARLY FROM A COMPARATIVE PERSPECTIVE THAT ANALYZES THE CONTEXTS OF BRAZIL AND THE UNITED STATES, TWO COUNTRIES THAT TAKE A RATHER DIFFERENT APPROACH REGARDING CORPORATE OWNERSHIP STRUCTURES. IN ORDER TO DO SO, IT REVIEWS THE PANORAMA OF DUAL CLASS STRUCTURES, THEIR MAIN CHARACTERISTICS AND THE UNIFICATION PROCESS THAT BOTH COUNTRIES UNDERWENT. ON TOP OF THESE DISCUSSIONS, THIS PAPER PRESENTS SOME ARGUMENTS TO EXPLAIN WHY THE DUAL CLASS STRUCTURE STILL PERSISTS BOTH IN BRAZIL AND IN THE U.S. (ALTHOUGH WITH VARIABLE INTENSITY), DESPITE ALL THE CRITICISM AIMED AT THE SEGREGATION OF CASH FLOW AND VOTING RIGHTS.

\section{KEYWORDS}

DUAL CLASS STRUCTURES; UNIFICATION; CORPORATE OWNERSHIP; ONE SHARE ONE VOTE.

\section{INTRODUCTION}

Dual class structure is a controversial corporate ownership strategy. The unbundling of cash flow and voting rights has been severely criticized worldwide and yet, the dual class structure persists as an alternative widely adopted by Brazilian firms ${ }^{1}$ and by part of the American firms. ${ }^{2}$ Why? 
This paper aims to answer this question, particularly from a comparative perspective that analyzes the contexts of Brazil and the United States, two countries that take a rather different approach regarding corporate ownership structures. In order to do so, it reviews the panorama of dual class structures, their main characteristics and the unification process that both countries underwent.

Section 1 reviews the dual structure rationale by assessing the general reasons why companies adopt a dual class share structure, the main implementation strategies used and the regulatory approach adopted by the U.S. and Brazil. Additionally, section 1 provides an overview of the dual class structure scenario in each country based on empirical evidence available in the literature.

Section 2 focuses on the unification process. This section analyzes the main problems associated with dual class structures and how the unification has been conducted in Brazil and in the U.S. It reviews the main determinations and implications of eliminating the dual class structure to understand the predominant trends governing corporate behavior in each country.

On top of the discussions developed in the previous sections, part 3 presents some arguments to explain why the dual class structure still persists both in Brazil and in the U.S. (although with variable intensity), despite all the criticism aimed at the unbundling of cash flow and voting rights.

Finally, the last section concludes this paper by wrapping up the main topics discussed, in an effort to draw a parallel on how such issues are dealt with in Brazil and in the U.S.

\section{THE DUAL CLASS STRUCTURE RATIONALE}

The separation of ownership and control between shareholders and management in firms with a single class of common stock results in conflicts of interests (JENSEN \& MECKLING, 1976). Management in control can reap private benefits from the corporation in detriment to shareholders' best interests. Likewise, shareholders may free ride on others' efforts to monitor the corporation. In order to mitigate such conflicts, Alchian and Demsetz (1972) pointed out five key rights to be held by shareholders, while decision making and monitoring is transferred to the board of directors. These five key rights are: (i) the right to residual cash flows; (ii) the right to elect and remove directors; (iii) the right to observe input behavior; (iv) the right to be the central party common to all contracts with inputs; and (v) the right to sell these rights (ALCHIAN \& DEMSETZ, 1972).

This paper focuses on the analyses of cash flow and voting rights and how these rights are unbundled in companies with a dual class structure, as opposed to a single class structure, in which such rights are combined. Dual class firms usually segregate cash flow and voting rights by creating different classes of shares with different rights. 
In the U.S., firms typically have a single class of common stock (a detailed analysis of the American context is found in section 1.5). The shareholder holds a right to a proportion of the residual cash flows of the corporation based on the interest in the company's equity. Residual cash flows are paid through dividends and at the liquidation of the company. In Brazil, firms with a dual class structure are predominant and thus voting rights and cash flow rights are commonly segregated (a detailed analysis of the Brazilian context is found in section 1.4).

As dual class share firms separate cash flow and voting rights, ownership and control are segregated in such a way that control is assured with (sometimes much) less equity interest than in single class firms, in which control generally arises from at least a 50\% equity ownership. Google Inc., for example, has two classes of stock. Class A shareholders have one vote per share, whereas class B shareholders have ten votes per share. As of 2009, co-founders Sergey Brin and Larry Page held $77.3 \%$ of class B shares (and no class A shares). ${ }^{3}$ Hence, they had the control of the firm while holding $58.3 \%$ of the voting stake and only $18.3 \%$ of the cash flow stake.

The analysis of the optimal design of share structures gained attention with the seminal works of Grossman and Hart (1988) and Harris and Raviv (1988), whose analyses concluded that the optimal share structure - from a shareholder wealth maximization perspective - presupposes cash flow rights and voting power in the same proportion. In the U.S., the one share one vote aphorism is praised as reducing the agency problems between shareholders and management while minimizing the chance that a value-increasing takeover by a rival would fail. In Brazil, the one share one vote is also acclaimed for increasing investor protection by reducing agency problems between minority shareholders and the controlling shareholder. Nevertheless, many prominent companies in both countries adopt a dual share structure. The following section explores some of the reasons why firms choose this path.

\section{I GENERAL REASONS WHY COMPANIES ADOPT A DUAL ClASS SHARE STRUCTURE}

Perhaps the most frequent reason why companies opt for a dual class share structure is to preserve the original founders' power while allowing access to the capital market. The dual class structure allows those with controlling interest and limited funds to, at the same time, retain control and use the equity markets for additional financing (DEANGELO \& DEANGELO, 1985, p. 35). This may be especially beneficial for firms that require large amounts of organization-specific human capital, whose projects are difficult for outsiders to value due to high levels of information asymmetry or for firms with high amenity potential, like the media industry (DEMSETZ \& LEHN, 1985). In the U.S., the structure has also been used by incumbent management to remain in control of the company once it goes public.

In the American context, another important role of the dual class structure is to act as a takeover defense mechanism. The structure protects management from hostile 
takeover threats when management holds a substantial part of the company's voting rights, usually through the use of multiple voting shares. Indeed, when management controls the firm with a majority of the voting rights, the takeover threat is basically contained. Dual class shelters management from the discipline of the market for corporate control (GILSON, 1987).

Finally, studies have shown that companies are more likely to adopt dual class structures, especially in the American context, in the following situations: (i) when management reputation has increased, either because of good past performance or due to reputable new management; (ii) when the company operates in industries with a substantial increase in takeover activity; and (iii) when the company drastically changes features, affecting its product market (e.g., relevant change in technology or entrance into a new market), requiring it to start making risky long-term investments with no guarantee of success in the short-run (CHEMMANUR \& JIAO, 2006, p. 7).

\section{I.2 IMPLEMENTATION STRATEGIES}

There are several ways through which the dual class structure can be implemented. The most common strategy in the U.S. is a dual class IPO. When a company decides to go public, it designs an equity capital structure comprised of more than one class of stock with different voting power. In the U.S., this structure usually takes the form of two classes of stock, one with ten votes per share and the other with one vote per share, although variations of this structure are not rare.

In Brazil, multiple voting shares are not allowed (Law of Corporations, article $110, \S 2)$. Brazilian companies can issue two classes of stock, one with one vote per share (common stock) and the other with no voting rights (preferred stock). Up until the early 2000s, Brazilian companies would introduce the dual class structure by going public offering only preferred stock, while the common stocks were held by the founders and not publicly traded. As of the mid 2000s, however, dual class IPOs were no longer the trend in Brazil. During this period, some companies (listed only with common stocks) have introduced dual class through follow on of preferred (non voting) shares. A few have promoted a dual class IPO. However, the majority of IPOs in Brazil since mid 2000s have been one class share listed in the Novo Mercado segment (see section 1.3 for details), because it facilitates the placement of shares. In fact, the only Brazilian companies that still opted for a dual class IPO in the last years were those public owned, such as Petrobras.

Some firms with the bulk of their revenues accrued in Brazil have recently opted to introduce the dual class structure through a rather sophisticated mechanism. They incorporate in a foreign country (e.g. they are not technically Brazilian firms) whose corporate law allows for multiple voting shares - usually the Bermudas, also because of its similarity with the British corporate law, which is familiar to investors - and issue in the Brazilian exchange (BM\&FBovespa, see details in section 1.3 below) the so-called 
Brazilian Depositary Receipts (BDRs), a security that allows foreign companies to raise capital in the Brazilian market (MAIA, 2012). Under this structure, these companies (that are formally foreign but materially Brazilian) are listed in the Brazilian market while having a dual class structure with super voting shares abroad. ${ }^{4}$ Although there is no legal impediment for companies to promote a dual class IPO in Brazil, the common choice is to avoid this path and opt for the BDR structure, as Agrenco, Cosan Limited, Dufry, GP Investments, Laep, Tarpon and Wilson, Sons did (MAIA, 2012, p. 16).

In the U.S., before July 1988, when the Securities Exchange Commission (SEC) ${ }^{5}$ introduced rule 19C-4 (hereinafter, SEC rule 19C-4, detailed in section 1.3), other implementation strategies were fairly common. Companies commonly introduced the dual class structure through recapitalization transactions such as "dividend sweeteners" and time phased voting plans.

In a "dividend sweetener" recapitalization, a company with a single class of shares created a new class of shares with less voting rights but with higher dividends (HOWELL, 2009, p. 18). Following the creation of the new class with enhanced cash flow rights and reduced voting power, the company gave its shareholders the option to convert their shares to this new class (HOWELL, 2009, p. 8). The ordinary shareholders that did not hold a relevant stake in the company were hence highly motivated to switch shares, since more dividends would accrue to them. Those blockholders of the original class not converted into the new one then, usually held enough voting rights to control the company.

In time phased voting plans, shareholders were segregated and voting rights distributed based on the length of time they owned the stock (HOWELL, 2009, p. 9). Under this strategy, a share gained a certain voting power (e.g., 10 votes per share) conditioned upon its holding for a minimum period of time (e.g., four years). The average shareholder who did not wish to hold his or her investment for too prolonged a period, ended up not enjoying enhanced voting power because he or she did not hold the share for sufficient time. Conversely, the block of shareholders holding shares for a prolonged period ended up with more voting power and control of the company, despite the reduced cash flow rights accruing to them.

Additionally, companies in the U.S. chose to implement dual class structure through spin-offs in cases where such strategy allowed for beneficial tax treatment (HOWELL, 2009, p. 10). Certain transactions had a minimized tax burden if they used a trust vehicle that retained substantial voting rights after a spin-off. To accomplish such retention, the establishment of a dual class structure was an effective path.

Finally, U.S. companies also implemented the dual class through the issuance of stock dividends (HOWELL, 2009, p. 10). In this case, the company usually issued a non-voting stock as a dividend for a voting stock, followed by an additional issuance of the new class of non-voting stock. This introduced a new class of shares with unbundled voting and cash flow rights. Dow Jones \& Co, Times Mirror Company, CMI 
Corporation and Baker Corporation are some of the companies that used this strategy to introduce a dual class structure (HOWELL, 2009, p. 10).

After SEC rule 19C-4 was issued, many of the previously mentioned strategies became impracticable due to regulatory constraints (as detailed in section 1.3) and most dual classes were structured via IPOs.

In sum, while in Brazil the main method for implementing dual class structures is through the issuance of BDRs, in the U.S., dual class IPOs are the most popular strategy. Thus, dual class structures can be implemented through the issuance of BDRs, through IPOs, through corporate restructuring that change voting and cash flow rights of a specific class of shares as well as through the issuance of a new class of stocks, usually with no voting powers and only with cash flow rights.

\section{I.3 Regulatory approach: U.S. v. BraZIL}

In the U.S., the unbundling of cash flow and voting rights dates back to the turn of the twentieth century, when there was the first issuance of non-voting stocks by International Silver Company, in 1898 (STEVENS, 1926). In the 1920s, companies began to issue two classes of common stock giving only one class the right to vote (HOWELL, 2009, p. 2).

In 1926, the issuance of non-voting common stock received its first public disapproval by the New York Stock Exchange (NYSE). The NYSE released a statement that it would review the matter of voting control carefully (HOWELL, 2009, p. 3). After the 1926 statement, the NYSE prohibited the issuance of non-voting securities, although it did not formally announce the prohibition until 1940 (HOWELL, 2009, p. 3). The restraint was kept until 1985, when the NYSE relaxed some of the voting rules in order to be more competitive with other American exchanges. Despite the prohibition of non-voting shares until 1985, some companies managed to get around the restriction by issuing classes of stock with inferior voting rights rather than no voting rights. ${ }^{6}$ Nevertheless, in 1985 only 10 NYSE firms had a dual class structure (SELIGMAN, 1986).

The American Stock Exchange (AMEX) adopted a less strict policy than the NYSE and it did not implement a non-voting prohibition until 1972 (HOWELL, 2009 , p. 4). In 1976, the AMEX issued the so-called "Wang formula" policy statement, determining the boundaries for dual class structure companies. According to this statement, the limited voting class had to have the ability to elect at least $25 \%$ of the board, the voting ratio could not be greater than 10:1, no additional stock could be issued which diluted the limited voting shareholders stake, superior voting rights would be lost if the number of these shares fell below a certain percentage and dividend preference was strongly recommended for limited voting stock (HOWELL, 2009 , p. 4). As of 1985, the AMEX had 60 companies (7\%) listed with dual class shares (SELIGMAN, 1986). 
The National Association of Securities Dealers (NASD) had no restriction on dual class structures and as of 1985, 110 companies listed in the NASDAQ (originally, National Association of Securities Dealers Automated Quotations) had a dual class structure (SELIGMAN, 1986).

Although there was public and congressional pressure for the three exchanges to formulate a uniform policy, negotiations took a long time to reach common ground. In fact, after 1985, all exchanges allowed for dual class structures and, in 1988, 336 firms (6.7\% of the publicly listed companies) used the structure (HOWELL, 2009, p. 5). With the increase in the use of this structure, more pressure from the Congress for regulation arose and as the discussion moved forward, the following view emerged: instead of prohibiting dual class structures, the focus of regulation became dual class recapitalizations that effectively coerced the existing shareholders into giving up their voting rights (HOWELL, 2009, p. 6). This rational was expressed by Gilson (1987, p. 11) who, while analyzing leverage buyout and dual class structures as substitutes, concluded that regulation prohibiting dual class recapitalizations was important, but it should not mean the banning of dual class structures. This approach would allow companies to enjoy the benefits of a dual class structure without the problem of coerced shareholders.

This proposal resulted in the issuance of SEC rule 19C-4 in 1988. Under the rule, the SEC prohibited self-regulatory organizations (such as the exchanges) from listing and trading the stocks of companies that issued new shares carrying more than one vote per share, but it allowed companies to issue shares with less than one vote per share and permitted those with unequal voting rights still to be traded (HOWELL, 2009, p. 6). As a technical matter, SEC rule 19C-4 added a new rule to the listing standards of each American national securities exchange making available transaction reports (under the Securities Exchange Act of 1934 rule 11Aa3-1, 17 C.F.R. § 240.11Aa3-1, 1990). While not a strict one share, one vote standard, SEC rule 19C-4 placed substantial limitations on the ability of U.S. corporations to adopt disparate voting rights plans. However, shortly after the rule was implemented, in 1990 the United States Court of Appeals for the District of Columbia Circuit unanimously ruled that the SEC had exceeded its authority in issuing the rule. ${ }^{7}$

Despite the ruling against the SEC rule 19C-4, the NASD, NYSE and AMEX all issued policies implementing rules similar to the SEC rule 19C-4 proposal (HOWELL, 2009 , p. 7). The AMEX, for example, adopted the restriction with the exception that inferior voting shares could be created if approved by two-thirds of the stockholders and a majority of non-insiders (BLOCK, 1991). In 1994, all three exchanges adopted a uniform policy, ${ }^{8}$ allowing companies with dual class structures to be listed and setting no limitation on voting rights for new public offerings. However, the policy barred companies from reducing their existing shareholders' voting rights through actions as "the adoption of time phased voting plans, the adoption of capped voting rights plans, 
the issuance of super voting stock or the issuance of stock with voting rights less than the per share voting rights of the existing common stock through an exchange offer" (Section 313.00 (B) of the NYSE Listed Company Manual). In sum, dual class IPOs were allowed freely, but follow on issuances had to avoid shareholder exploitation.

In spite of the regulatory efforts to develop a uniform policy minimizing the risk of shareholder exploitation, the dual class structure is still strongly criticized in the U.S. More details of the American panorama on dual class companies are provided in section 1.5 .

In Brazil, dual class structures date back from the beginning of the development of the capital market. ${ }^{9}$ Before the 1960 s, Brazilians mainly invested in real estate, avoiding investments in securities. An economic environment of rising inflation in the late 1950 s, coupled with an interest rate legally capped at $12 \%$ per year (the Usury Law), strongly limited the development of an active capital market. ${ }^{10}$ Things began to change in 1964, when the government promoted major economic reforms and enacted the basic legislation regulating the financial and capital markets. The major events, however, happened in 1976, when Congress enacted the main body of corporate law ${ }^{11}$ (Federal Law 6,404/76, as amended, hereinafter, Law of Corporations) and created the Brazilian Securities Commission (Comissão de Valores Mobiliários, hereinafter CVM).

Until the mid 1960s, Brazil had 27 stock exchanges, operating as nonprofit organizations regulated by the Federal Government. In 2000, the 10 remaining exchanges were integrated into a single entity, the São Paulo Stock Exchange (BOVESPA). ${ }^{12}$ Since then, the BOVESPA (operating under supervision of the CVM) has concentrated all securities trading in Brazil. In 2007, BOVESPA was reincorporated as a corporation. A few years later, in 2008, the BOVESPA merged with the Brazilian Mercantile and Futures Exchange (BM\&F) to become the BM\&FBovespa, one of the biggest securities exchanges in the world.

From 1940 to 1976, every listed company in Brazil could have non-voting stock representing up to $50 \%$ of its equity capital (Federal Decree 2,627, issued on September 26, 1940). After 1976, this legal ceiling was raised to two-thirds of the company's equity (Law of Corporations, article 15, § 2) and later reduced again to 50\% in 2001 (Federal Law 10,303, October 31, 2001). However, companies listed prior to 2001 were allowed to keep preferred stock up to two-thirds of the equity capital, as long as they abided by the new rules regarding preferred stockholders' rights (Law of Corporations, articles $8, \S \S 1$ and 3). Thus, a dual class structure - comprised of common stock with one vote per share and preferred stock with no voting powerhas historically been a substantial part of Brazil's corporate structure. More details on the role of this approach are provided in section 1.4.

Hence, the dual class structure is so embedded in Brazil's corporate tradition that a regulatory attempt to broadly limit the structure would likely meet many obstacles, 
especially from established interest groups that benefit from the status quo. In order to effectively deal with the historical corporate setting and still foster the development of the capital markets, the BM\&FBovespa created different trading segments with separate standards for listing. Besides the traditional segment, the exchange offers four other segments that companies may voluntarily adhere to: (i) Bovespa Mais ("More”); (ii) Level 1; (iii) Level 2; and (iv) Novo Mercado ("New Market").

Most relevant to this paper is the Novo Mercado segment because it is the only one that absolutely prohibits companies from having a dual class structure (e.g., only single class companies can be listed in this segment). ${ }^{13}$ The Novo Mercado was created in 2000 on the premise that reduction in investor perceptions of risk would have a positive effect on share values and liquidity (SANTANA et. al., 2008, p. 1). The segment was aimed at companies committed to adopting high standards of corporate governance beyond those legally required, including rules increasing shareholder rights and mandating more comprehensive disclosures. ${ }^{14}$ The BM\&FBovespa believed that investors would perceive their risks to be lower if they were granted additional rights and guarantees and also if the information asymmetry between the controlling shareholders/management and market participants was narrowed (SANTANA et al., 2008 , p. 1). The segment has received much praise. The Wall Street Journal assessed the Novo Mercado as a "listing for newly public companies with U.S.-style corporategovernance standards. Partly as a result, foreign investors have bought up $74 \%$ of shares in new listings" (REGALADO \& LUCCHETTI, 2007).

The Novo Mercado limitation of non-voting shares aimed at reducing opportunities for abuse by giving minority shareholders the ability to voice their concerns and to attempt to influence corporate action (GILSON et al., 2010, p. 17). It also limited the controlling shareholders' incentives for expropriation of minority shareholders by removing the wedge between voting and cash flow rights (GILSON et al., 2010 , p. 17). Brazil's Novo Mercado is seen as a paradigmatic example of regulatory dualism, as a strategy to mitigate political opposition to reforms by protecting the status quo while allowing other firms to be regulated by a new parallel regime that is more efficient (GILSON et al., 2010, p. 1). Indeed, 85\% of the companies listed in Novo Mercado are "new entrants", which means their IPO put them in this segment (GORGA, 2008, p. 1).

Although Brazil and the U.S. have chosen different regulatory approaches (while Brazil is betting on the regulatory dualism, the U.S. exchanges adopt a uniform policy that keeps them competitive), understanding how regulation is perceived is crucial to comprehend the analysis that follows.

\section{I.4 THE BRAZILIAN CASE}

From the early days of its corporate history, Brazil has had a family based capitalism with concentrated ownership as the primary rule and equity capital comprised of common 
and preferred stocks. The main purpose of preferred stock is to create an environment that allows Brazilian firms to get financed by the capital markets while permitting the founders to remain in control of the firm and provide investors with additional assurance of profitability or recovery of investment (LAMY FILHO \& PEDREIRA, 1995, p. 193).

Currently, companies can have up to $50 \%$ of their equity capital comprised of preferred stock (Federal Law 10,303/01, article 15, § 2). After consecutive legislative reforms, presently preferred shares must have at least one of the following benefits: (i) priority in the distribution of fixed or minimum dividends, or (ii) priority in the residual claim, with or without premium. The bylaws can overlap such benefits (Federal Law 10,303/01, article 17, § 2). Additionally, in order to be listed, preferred shares shall be entitled, alternatively: (i) to the same dividends paid to common stock, of at least $25 \%$ of the net profits for the fiscal year, with priority to receive minimum dividends corresponding to at least 3\% of the book value per share; or (ii) to dividends $10 \%$ higher than those paid to common stock; or (iii) to the same dividends as paid to common stock combined with tag along rights in case of a tender offer to acquire control (Federal Law 10,303/01, article 17, §1). Thus, preferred stocks with fixed dividends and no right to participate in the residual profits can no longer be traded in the market.

Legislative reform also improved preferred stockholders' political rights. Preferred stockholders with $10 \%$ of the firm's equity capital have the right to elect and remove (in a separate vote) one member of the board of directors. The controlling shareholder cannot vote in this election. Moreover, preferred stocks' voting rights are restated in case of nonpayment of dividends for a period of three consecutive years (or less, as otherwise provided by the bylaws), until non-cumulative dividends are distributed again or delayed cumulative dividends are paid (Law of Corporations, article $141, \S 4)$.

Lastly, changes to preferred stocks' benefits must be previously approved or later ratified by the majority of the preferred stockholders in a special meeting (Law of Corporations, article 136, §1). Dissenting preferred stockholder has legally assured appraisal rights (Law of Corporations, article 137, I and II). This brief overview of the role of preferred stocks should help contextualizing the reality of the dual class structure in Brazil.

From this framework, it is clear that the Law of Corporations was shaped to deal with dual class companies. In Brazil, the figure of a controlling shareholder is very common, as well as the unbundling of cash flow and voting rights. Most companies outside Novo Mercado trade primarily preferred stocks, which results in high illiquidity of the common (voting) stock. Despite an extensive literature suggesting that private benefits of control can explain price differentials between classes of stocks with different voting rights, in Brazil the price differential between voting and nonvoting stocks was found 
to be negative for several companies in the period between July 1994 and September 2002 (SAITO, 2003, p. 106). This study shows how liquidity is relevant to the determination of relative prices (SAITO, 2003, p. 106).

In Brazil, 74\% of listed companies had a dual class structure as of 2007 (BORTOLON \& LEAL, 2009, p. 8). This represented a decrease from 2000, when the percentage of dual class companies was $89 \%$. The chart below shows the evolution of the percentage of companies adopting dual class structures:

\section{Graph 1 - COMPANIES WITH DUAL CLASS STRUCTURE}

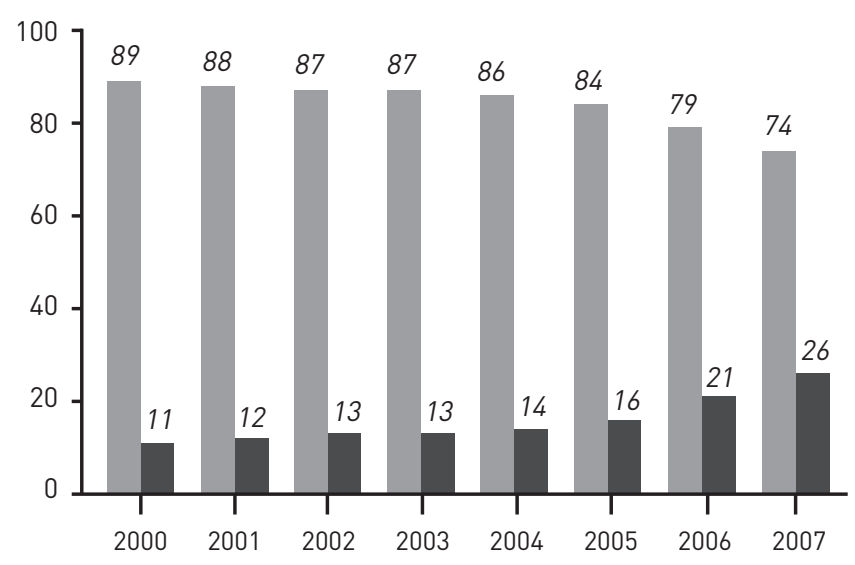

Source: Bortolon \& Leal (2009, p. 8).

The movement for a reduced participation of preferred stocks in firms' equity follows a worldwide trend to expand the volume of common shares trading in the market, proportionally reducing the space once occupied by preferred stocks (PINTO JUNIOR, 2011, p. 9-10). It is also a response to the strong criticism the Brazilian dual class structure has been under, especially regarding minority shareholder protection (GILSON et al., 2010; SANTANA, 2008). Thus, there is a clear trend for the unification of dual class structures in Brazil, which will be analysed in detail in section 2.2.

\section{5 The American CASE}

The American case is very different from the Brazilian. Initially, there is no comprehensive statutory regulation of non-voting stocks (as opposed to extensive regulation of Brazilian preferred stocks). Moreover, the American corporation typically has a 
dispersed ownership structure, although controlling shareholders are found in a limited number of companies.

Dual class structures are also more sophisticated in the U.S. The possibility of having shares with multiple voting rights provides more flexibility on how the dual class structures are designed and implemented, as discussed in section 1.2 above. The result is that the separation of cash flow and voting rights in American dual class firms provides outside investors with limited control rights even when their fractional ownership may give them substantial cash flow rights.

In the U.S., 7.4\% of the companies had a dual class structure as of $2007(11.5 \%$ of NYSE companies, 5.1\% of AMEX companies and 5.5\% of NASDAQ companies) (HOWELL, 2009, p. 24). This percentage has been fairly stable for the past decade, as shown by the chart below:

\section{GRAPH 2 - COMPANIES WITH DUAL CLASS STRUCTURE}

\section{VS. COMPANIES WITH SINGLE CLASS STRUCTURE}

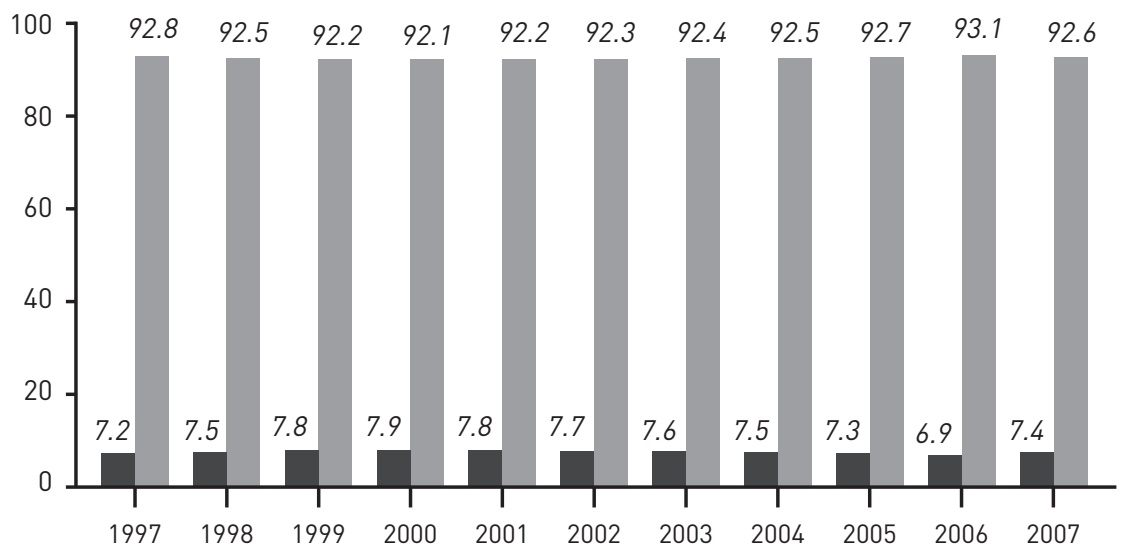

Source: Howell (2009, p. 24).

When compared to the Brazilian scenario, American companies clearly make proportionally much less use of the dual class structure, which is consistent with the dispersed ownership pattern. Companies that do adopt a dual class structure have a controlling shareholder that holds on average $60 \%$ of the voting rights and $40 \%$ of the cash flow rights. The most common arrangement is a 10:1 structure in which the superior class has ten votes per share and the inferior class has one vote per share. Moreover, insiders maintain a majority of voting rights without holding a majority of cash 
flow rights in only one-third of dual class firms (GOMPERS \& METRICK, 2008, p. 9), which is a fairly low percentage in the context where dual class structures are generally perceived as providing control unbundled from cash flow rights.

Studies have shown that dual class firms are generally larger than single class ones in the U.S. As of 2008, the median dual class company had \$482 million in assets as opposed to $\$ 138$ million for the median single class company (GOMPERS \& METRICK, 2008, p. 10). Similarly, as of 2008, dual class firms had a median market value of $\$ 295$ million whereas single class firms had \$100 million (GOMPERS \& METRICK, 2008, p. 9). Overall, dual class firms represented $8 \%$ of the market capitalization (GOMPERS \& METRICK, 2008, p. 9). Moreover, on average, dual class firms were 35\% more leveraged than single class firms (HOWELL, 2009, p. 14).

Most dual class structures in the U.S. are implemented by IPOs (HOWELL, 2009 , p. 36). Studies show that dual class IPOs in the U.S. are more prevalent in three kinds of firms: (i) those operating in industries in which value can be created by pursuing long-term goals while ignoring short-term trends (e.g., the newspaper and media industry, where sacrificing editorial integrity in pursuit of short-term profits can be disastrous); (ii) firms that are family owned or run by founding entrepreneurs, who tend to have a high reputation in managing the firm; and (iii) those firms characterized by large private benefits of control (CHEMMANUR \& JIAO, 2006, p. 6). If the private benefits of control are larger than the aggregate reduction in share value (assuming that a single class IPO would increase the share value), then there is scope for insiders to negotiate with other potential investors and go public with a dual class structure (GOMPERS \& METRICK, 2008, p. 15).

These findings are consistent with Howell's empirical evidence (2009, p. 14) that the main industries that adopt dual class structures in the U.S. are communication and publishing (e.g., The New York Times Co., Washington Post Inc. and Dow Jones \& Co.), in which there are significant benefits of maintaining control. A study conducted in 2001 showed that dual class firms are concentrated in five industries: communications, business services, printing and publishing, retail and machinery (GOMPERS \& METRICK, 2008, p. 11). This trend has been recently confirmed by the dual class IPOs of Zynga, Grupon, LinkedIn and Facebook.

Finally, among those companies with a dual class structure as of 2009, 22\% of superior voting stocks are freely traded (SBA, 2010, p. 20). Despite having comparatively many fewer companies with dual class structure than Brazil, the U.S. also is and has historically been under strong criticism for allowing the unbundling of voting and cash flow rights. Hence, the unification process of dual class shares has been a trend in both countries. The following part analyzes the development of this process. 


\section{THE UNIFICATION PROCESS}

\section{I Problems with the dual Class structure}

The criticism of dual class structures is well grounded. There are many reasons why the arrangement is often censured and this section assesses the main arguments against dual class structures.

First, the dual class structure aggravates agency conflicts ${ }^{15}$ between shareholders and managers/controllers arising from the divergence between voting power and cash flow rights (BEBCHUK et al., 1999). In Brazil, where firms usually have a controlling shareholder, the agency problem is mainly between the controlling shareholder and minorities, whereas in the U.S., where dispersed ownership is predominant, the agency problem is more severe between management and shareholders. In dual class companies, management ends up having control of the firm despite holding only a small share of the firm's equity capital, as opposed to single class companies, in which control requires a stake of at least $50 \%$ of the equity capital. A large stake such as that reduces the controlling shareholder's incentives to use private benefits of control in detriment to minority owners (e.g., misappropriation of corporate funds). Likewise, in companies with dispersed ownership and a single class structure, the risk of takeover and the market for corporate control serve as strong incentives for management to be efficient and not take advantage of shareholders. This is why single class firm are seen as the best structure to deal with agency problems.

In dual class structures, agency problems are more severe because shareholders controlling disproportionally more voting rights than cash flow rights bear a smaller portion of the financial consequences of their decisions while having greater ability to prevent and even block changes in corporate control that could threaten their private benefits and continued employment at the firm (MASULIS et al., 2008, p. 4). Some evidence of management profiting from private benefits of control can be found in the fact that CEO compensation is significantly higher in companies with a wider divergence between insider voting and cash flow rights (MASULIS et al., 2008, p. 10). In short, dual class structures encourage irresponsible behavior from those holding large voting power and a limited cash flow stake. In Brazil this problem is somewhat alleviated by the fact that the law limits the divergence between voting and cash flow rights (non-voting shares can represent a maximum of $50 \%$ of the equity capital) (see section 1.4 for more details).

Besides agency problems, the unbundling of voting and cash flow rights also raises a serious concern about minority shareholder exploitation. Without a voice, shareholders holding only cash flow rights cannot influence the company's decision-making process and they might be exploited by a majority shareholder (as in the Brazilian case) or entrenched management (as in the American case). Moreover, shareholders holding mostly cash flow rights have a harder time holding managers accountable for their actions. 
Hence, dual class structures can have a negative impact on investor equality. From an institutional investor's perspective, Li, Molina and Zhao (2008, p. 16-17) found that institutional ownership in dual class firms is $11 \%$ lower than it is in single class firms, after controlling for other determinants of institutional investment. Although institutions of all types hold less of a stake in dual class firms, this avoidance is more pronounced for long-term investors with strong fiduciary responsibilities than for short-term investors with weak fiduciary duties (LI et al., 2008, p. 32). Cross-sectional tests in the U.S. show that, as of 2007, the aggregate institutional ownership in dual class firms was about 3.6\% lower than in single class companies, after controlling for a host of factors that affect institutional investment in stocks (LI et al., 2008, p. 32).

In the case of dual class companies with a founding shareholder that uses the structure to assure control over the company's future, an incompetent heir can pose serious obstacles to the founder's posterity plans (SBA, 2010, p. 19). Hence, as the controller transfers his shares to the next generation of the family business, the certainty of a bright future can be disturbed if the incoming heir is not as skilled as the founder. An unskilled heir, or even intra-family conflicts, can basically threaten the company's future existence and undermine all previous efforts put into the business.

Moreover, dual class companies also have less or no incentive for change in times of difficulty. An entrenched management or a controlling shareholder suffers less external (minority) pressure when times are difficult and change is needed. Conversely, single class firms (especially those with dispersed ownership) are under much more pressure from minority shareholders for change in problematic periods. The possibility of shareholder proxy access introduced recently by the $\mathrm{SEC}^{16}$ is a part of this force.

There are also papers suggesting that dual class structures negatively affect firm value. Companies' value has been positively associated with insiders' cash flow rights and negatively associated with insiders' voting rights (GOMPERS \& METRICK, 2008, p. 6). Masulis, Wang and Xie (2008, p. 2) argue that the dual class structure adversely impacts value to shareholders because the marginal value of cash decreases in the divergence between insider voting rights and cash flow rights. Moreover, they argue that this structure encourages value-destroying acquisitions. As insiders control more voting rights relative to cash flow rights, they are more likely to make shareholder value destroy acquisitions that benefit themselves (MASULIS et al., 2008 , p. 3). Finally, they argue that capital expenditure contributions have significantly less impact on shareholder value in firms with a greater divergence between insider voting rights and cash flow rights, suggesting that managers of these companies are more likely to make large capital investments to advance their own interest (MASULIS et al., 2008, p. 20). All these factors result in a firm with lower value. Some empirical evidence exists to corroborate these assertions. Villalonga and Amit (2006) found that control-enhancing mechanisms, such as dual class structures, had 
a negative and significant effect on the value of S\&P 500 firms between 1994 and 2000. Consistent with this result, the same authors found that the wedge between voting and cash flow rights is negatively associated with firm value for family firms (VILLALONGA \& AMIT, 2009).

Furthermore, a dual class structure serves as an effective anti-takeover mechanism in the American context (as briefly mentioned in section 1) (JARRELL \& POULSEN, 1988). Interesting evidence of this increased protection against takeover enjoyed by dual class companies can be found in the average age of these companies. Dual class firms are generally significantly older than single class firms, with an average age of 12.87 years versus an average age for single class firms of 9.60 years (as of 2001) (GOMPERS \& METRICK, 2008, p. 11). Indeed, few takeover defenses are more likely to be successful than dual class capitalization (SELIGMAN, 1986). The flipside of this situation is that it prevents minority shareholders from reaping the benefits of an average takeover premium of approximately 16-20\% (ANDRADE et al., 2001; BOONE \& MULHERIN, 2007). This exploitation of minorities in the takeover context is regarded as a negative feature of the dual class structure.

In sum, dual class structures can pose a wide range of problems both from an individual (shareholder) perspective - such as the risk of exploitation and negative impact on firm value - and a broader, public policy perspective - such as the detrimental effects on the market for corporate control. The problems with the dual class structure mentioned above are definitely more acute in the United States than in Brazil due to the historical patterns of corporate ownership, despite the small number of firms adopting this strategy in the U.S. Nevertheless, both countries have been facing a trend towards unification. The empirical evidence of this process is outlined below.

\subsection{EMPIRICAL EVIDENCE IN BRAZIL}

Pinto Junior (2011, p. 24) led a comprehensive study of dual class unifications in Brazil. He reviewed all unifications that took place between 2000 and 2010 to analyze the main determinants and implications of this process. Within this period, 82 companies listed in the BM\&FBovespa eliminated preferred stocks from their equity capital, thus adopting a single class structure. The chart below shows the evolution of the unification process: 


\section{GRAPH 3 - NUMBER OF COMPANIES UNIFYING DUAL CLASS STRUCTURE $(2000-2010)$}

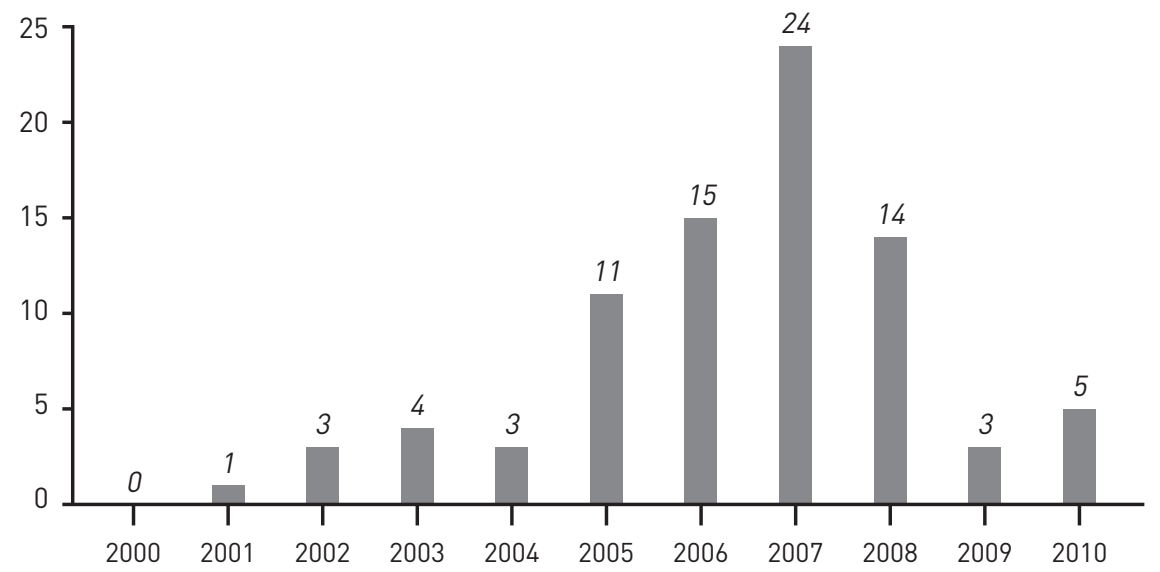

Source: Pinto Junior (2011).

The chart shows that the unification trend increased in 2005, when the Brazilian capital market was heating up, and it reached a peak in 2007, when the BM\&FBovespa registered the largest number of IPOs in a year (64 IPOs, compared to only 4 in 2008 and 26 in 2006). ${ }^{17}$

About $52 \%$ of the unifications were compulsory, e.g, were approved by a majority of the voting capital and obtained the approval of the preferred stockholders at a special meeting, making the unification binding on all shareholders (PINTO JUNIOR, 2011, p. 25). Only 26\% of the unifications were voluntary (PINTO JUNIOR, 2011 , p. 25). Additionally, only 4\% of companies went back to having dual class structures by issuing preferred shares after the unification (PINTO JUNIOR, 2011 , p. 25).

Also, $71 \%$ of the unifications used a conversion rate of $1: 1$, meaning that for every preferred stock redeemed, the shareholder was entitled to one common stock (PINTO JUNIOR, 2011, p. 26). For the remaining companies, 12\% adopted conversion rates other than $1: 1$ and $17 \%$ did not disclose the conversion ratio adopted (PINTO JUNIOR, 2011, p. 26). Regarding the corporate context, 78\% of the companies conducted the unification process as an isolated transaction whereas $16 \%$ used corporate restructuring transactions to unify the shares (PINTO JUNIOR, 2011, p. 27). 
The study also identified the main determinants that led dual class companies to become single class. By analyzing the justifications provided by the company's proxies, the study identified that the most common reason for unification - given by $52 \%$ of the firms - was to enter the Novo Mercado listing segment (see section 1.3), which requires that companies have equity capital comprised solely of common stocks (PINTO JUNIOR, 2011, p. 25). From this perspective, unification enhances these companies' governance practices. A similar study conducted by Bortolon and Leal (2009, p. 14), also analyzing the trends of the unification process of Brazilian firms, concluded that the main reason why companies converge to single class is to increase share liquidity. This finding is particularly relevant when the price difference between common and preferred stock is considered (see section 1.4 for details). The authors also identified the perspective of entering the Novo Mercado listing segment as a very relevant reason for companies to eradicate non-voting shares (BORTOLON \& LEAL, 2009, p. 14).

In analyzing which companies were more likely to abandon non-voting shares, Bortolon and Leal (2009, p. 29) identified three characteristics common to the firms that underwent the unification process: (i) they faced lower dilution of the original controllers' voting power (smaller wedge between cash flow and voting rights); (ii) they paid lower dividends; and (iii) their shares had lower liquidity in the market.

There is also extensive review of the implications of the unification process. Perhaps the most significant implication is that in the great majority of the cases, the controlling shareholder does not exit the structure through the unification process, although this reduces its voting power (BORTOLON \& LEAL, 2009, p. 29). ${ }^{18}$

With regards to firm value, $33 \%$ of the companies that unified their shares had an increase in market value, 12\% kept it stable and 29\% faced a decrease in market value (PINTO JUNIOR, 2011, p. 27). Although the majority of the firms experienced a positive market reaction to the unification process, the relevance of this result can be questioned when compared with the percentage of companies that suffered a negative value impact, which corroborates the argument that the evidence of increased value following unification of dual class structures is inconsistent.

Moreover, the liquidity motivation alleged by the firms entering the unification process was sucessfully met as companies faced increased liquidity under a single class structure (BORTOLON \& LEAL, 2009, p. 20). Liquidity is also important because it is a relevant criterion affecting a company's ability to partcipate in the Ibovespa index. ${ }^{19}$ Being part of the index portfolio is important because the company becomes a part of other portfolios that try to replicate that index's performance. Indeed, at least 10\% of the companies that underwent the unification process were included or increased their participation in the Ibovespa (PINTO JUNIOR, 2011, p. 28).

In sum, although the dual class structure is predominant in Brazil, there is a clear unification trend in recent years. The two major drivers of this trend are (i) the companies' desire to list in the Novo Mercado segment, as this transmits commitment 
to higher standards of corporate governance to investors, and (ii) the increase in share liquidity.

\subsection{EMPIRICAL EVIDENCE IN THE U.S.}

Studies have shown that firms which had a dual class IPO are more likely to unify their shares under three different situations: (i) in case of poor performance subsequent to the IPO or decline in management's reputation; (ii) following a change in incumbent management (e.g., retirement of the founder and transfer of control to professional management); (iii) due to maturing of the firm's industry (e.g., from an industry characterized by innovative products requiring risky long-term investments to one characterized by less risky investments with smaller changes across product cycles) (CHEMMANUR \& JIAO, 2006).

Howell (2001) performed an extensive study of 253 companies that underwent the unification process between 1989 and 2007. The chart below shows the evolution of the unification process in the U.S.:

\section{GRAPH 4 - NUMBER OF COMPANIES UNIFYING DUAL CLASS STRUCTURE $(1993-2007)$}

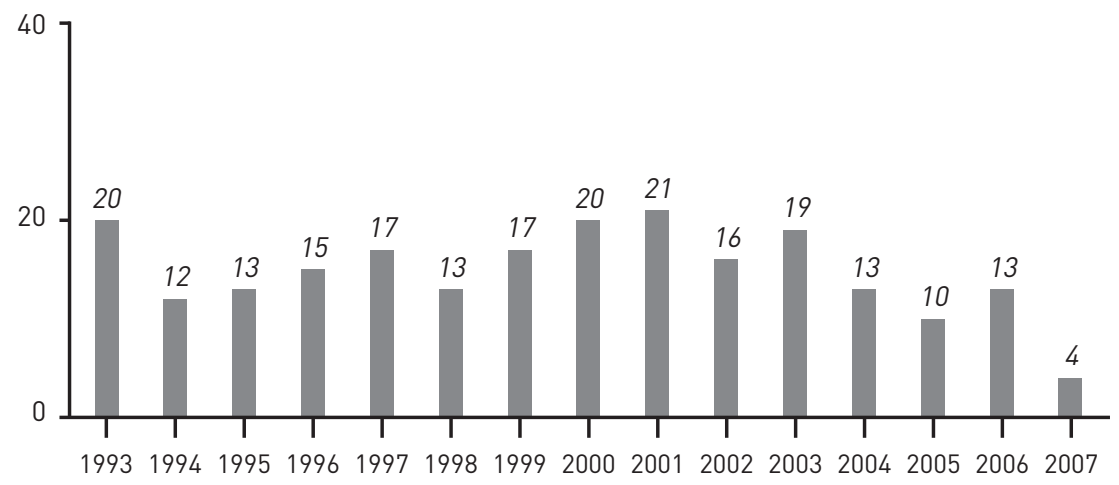

Source: Howell (2011, p. 31).

From 1988 to 2007, over 1,100 publicly traded companies used the dual class structure. Despite the structure's effectiveness in maintaining control, approximately one-fourth (253) of these firms decided to adopt the single class structure.

Although there is no clear trend in the elimination of dual class structure frequency (as opposed to in Brazil), there does seem to be an increase in occurrence beginning in 
1992, after the exchanges began implementing dual class policies similar to SEC rule 19C-4 (see section 1.3 for details on the rule).

About $23 \%$ of these conversions were originated by shareholder proposals, while $20 \%$ of the firms used an automatic (pre existing) conversion clause, based on conditions that trigger the conversion of the classes of stock (HOWELL, 2011, p. 1). Usually this mechanism works as follows: once the superior voting stock falls below $\mathrm{X} \%$ of the capital equity, there will be an automatic conversion of the superior voting stock into the restricted voting stock. When such automatic conversion clause is absent, firms promoted unification by converting restricted voting shares to superior shares (in 19\% of the cases) or by converting superior voting shares into restricted shares (in $14 \%$ of the cases) (HOWELL, 2011, p. 32). Under different strategies, $16 \%$ of the companies unified their shares through mergers or corporate reorganization and $7.5 \%$ as part of bankruptcy or a litigation proceeding (HOWELL, 2011, p. 32).

In 95 firms, superior shareholders voluntarily eliminated the dual class structure by means of a share conversion or a shareholder proposal. For these 95 firms, blockholders held on average $51.4 \%$ of the voting power prior to the elimination of the superior share class (HOWELL, 2011, p. 3) and lost half of their voting power during the year of the unification, going from $51.4 \%$ of voting power to $26 \%$ (HOWELL, 2011, p. 1).

The most common reason alleged by the companies eliminating the dual class structure is to increase liquidity, mentioned by 70\% of firms (HOWELL, 2011, p. 14). This is consistent with the fact that in approximately $85 \%$ of the dual class firms, only the restricted voting class trades publicly (as of 2008) (GOMPERS \& METRICK, 2008 , p. 3). This severely restricted the liquidity of the superior voting class. Other reasons given by the companies were: (i) to simplify the capital structure (43\%); (ii) to eliminate confusion among investors and analysts (43\%); and (iii) to align voting rights with the economic risks of ownership (43\%) (HOWELL, 2011, p. 14).

There is also extensive literature analyzing the implications of the unification process. With regards to increase in firm value, despite some controversy (better discussed in section 3), studies have found there is a positive announcement effect to the unification both in terms of share value and market capitalization (HOWELL, 2009, p. 39). With more of a relative approach, Chemmanur and Jiao (2006, p. 7) developed a model which predicts that the announcement effect of a share unification will be positive (and the firm's operating performance will improve subsequently) if the current reputation of incumbent management is low enough and it will be negative (and the firm's operating performance will deteriorate subsequently) if this reputation is high enough.

Additionally, unification tends to increase the participation of institutional investors in the firm's equity since these investors usually prefer to commit capital in single class firms. Empirical evidence shows that following the unification of a dual class structure, 
there is a substantial increase in the institutional ownership of the unifying firms, over and above the change in institutional ownership experienced by non-unifying dual class firms. The unification is associated with a $10.8 \%$ increase in total institutional ownership and, when compared to the pre-unification fractional ownership by institutional investors (almost 35\%), it represents a 30.9\% increase (LI et al., 2008 , p. 22). These findings suggest that institutional investors are truly concerned about the poor corporate governance associated with dual class companies, and that they significantly increase their investment after the structure is removed (LI et al., 2008, p. 22).

Regarding the role of the original blockholders, they usually maintain or slightly increase their voting power before the unification, but then significantly decrease their voting power in the three years subsequent to the removal of the dual class (HOWELL, 2011, p. 1). Two-thirds of the decrease in voting power is due to reductions in blockholder holdings as oppose to share dilutions (HOWELL, 2011, p. 1). For the 95 firms that removed their dual class structure through a shareholder proposal or by the superior voting shareholders simply converting their shares, blockholders lost an average of $50 \%$ of their voting power in the year of the unification, reducing their holdings to $15 \%$ of the voting power three years after unification (HOWELL, 2011, p. 24). Over 40\% of blockholders completely exited the firm within three years (HOWELL, 2011, p. 24).

In sum, blockholders are willing to lose significant portions of voting power in order to increase share liquidity, including of their own shares. By demonstrating that blockholders are willing to give up large portions of voting power in order to gain liquidity, empirical evidence suggests an important value of blockholder liquidity (HOWELL, 2011, p. 24).

\section{Critical Review: Why do dual Class structures Resist despite it all?}

The previous sections discussed the scenarios of dual class companies both in Brazil and in the U.S., their main characteristics and the trend towards elimination of the structure. The paper reviewed the key determinants and implication of the unification of dual class structures mainly from an empirical perspective. Despite the very different corporate environments in which the unification phenomenon has been taking place, clearly both Brazilian and U.S. firms have been following a unification trend, for both common and particular reasons. The question that remains is: why, in spite of all the problems associated with dual class firms and all the reasons vindicating unification, do some companies still prefer to stick with the dual class structure? This section suggests some answers to this question.

Firstly and perhaps more intuitively, one size does not fit all. In other words, single class firms may provide many benefits to different constituencies, but there are 
some circumstances in which such benefits are not perceived as relevant enough to justify unification. An example of this circumstantial approach can be found in the American context of the 1980 s, when the boom in takeovers led many companies to adopt a dual class structure as a protective device. In that particular circumstance, the potential benefits of having a single class structure were not enough to prevent the adoption of dual class, in the face of the potential damages arising from the threat of takeovers.

Likewise, in many circumstances, dual class structures might not trigger many of the agency problems discussed in section 2.1. Indeed, a large majority - two-thirds of the American firms with dual class structures have insiders with the majority of voting rights also holding the majority of cash flow rights (GOMPERS \& METRICK, 2008). This distribution of rights acts as a deterrent against minorities' exploitation since the potential exploiter is likely to hurt itself substantially too. Although there is no such statistical assessment of Brazilian firms with dual class structures, my guess is that a similar if not more pronounced situation is found there. Thus, one reason that may explain the persistence of dual class structures is that oftentimes, in practice, there are limited negative agency impacts attributable to the structure.

From an alternate approach, Pajuste (2005, p. 7) suggests that dual class companies operate in what she calls dual class "equilibrium". According to this perspective, minority shareholders take into account the fact that the controlling shareholder enjoys private benefits of control and as a consequence minorities adjust the price they are willing to pay correspondingly. Minority shareholders enjoy a discount in the share value, corresponding to the expected cash flow after the extraction of the private benefits of control (PAJUSTE, 2005, p. 7).

Dual class structures have also been considered an intermediate level in the firm life cycle (DEANGELO \& DEANGELO, 1985, p. 61). Based on this view, the dual class allocation of ownership rights suggests that these firms can be perceived as having an intermediate organizational form somewhere in between the dispersed ownership structure and the closely held firm. Hence, the dual class structure is more likely to be employed in situations which managerial vote ownership yields benefits (e.g., by encouraging managerial investment in firm-specific human capital), but personal wealth constraints faced by managers imply that investments can be made only if substantial amounts of equity are raised in the capital market (DEANGELO \& DEANGELO, 1985, p. 61). This rationale is consistent with the view dual class shares are temporary structures kept until when the firm needs new equity capital for further expansion and growth (AMOAKO-ADU \& SMITH, 2001).

One line of research suggests that dual class structures exist when there are countervailing efficiency benefits that offset the agency costs associated with the structure (for details on agency costs, see section 2.1) (KHANNA \& PALEPU, 1999). Once identified, such benefits can explain the persistence of dual class structures. 
The criticism made to this approach is that dual class structures are common in countries with lax corporate rules, although the agency costs of such structures tend to be greater in these countries (BEBCHUK et al, 1999a, p. 22). Thus, in order to prove this hypothesis, the research would have to identify countervailing efficiency benefits that are likely to be greater in countries with lax rules (BEBCHUK et al, 1999a, p. 22).

A different theory of corporate ownership structure suggests that dual class structures exist in public companies (e.g., after dual class IPOs) and persist when there is large private benefit and thus control is valuable enough (BEBCHUK, 1999b, p. 37). A controlling shareholder can rationally choose to sacrifice some firm value in order to maintain private benefits of control. The ability to control editorial policy at a newspaper (DEANGELO \& DEANGELO, 1985), ${ }^{20}$ corporate strategy at a software company or brand identity at a consumer company can all bring utility to manager-owners (GOMPERS \& METRICK, 2008, p. 41). Such benefits can outweigh possible financial losses, particularly if the insiders are already wealthy. The recent Facebook dual class IPO appears to have met many of these elements, as it is a firm in the media industry, with a particular corporate strategy and a wealthy CEO.

The so-called rent-protection theory advocates that controllers of companies with large private benefits use the unbundling of voting and cash flow rights to prevent others from taking over control and enjoying such benefits (BEBCHUK, 1999b, p. 37). Moreover, maintaining a lock on control enables blockholders to capture a larger portion of the surplus from value-producing transfers of control (BEBCHUK, 1999b, p. 37). This theory also indicates that a corporate law system that effectively limits private benefits of control, allows for a more efficient choice of ownership structure (BEBCHUK, 1999b, p. 37).

Considering that controlling shareholder structures are common, where investor protection is weak (LA PORTA et al., 1999), ${ }^{21}$ the rent-protection theory is a plausible explanation for the Brazilian and the American scenarios. While the U.S. is purportedly a country where private benefits of control are small because investor protection is high (and ownership is dispersed), Brazil is regarded as a country with large private benefits of control (and concentrated ownership). This is corroborated by empirical evidence finding a ratio of value of control to value of equity equal to 0.65 for Brazil, (a high-end value) (DYCK \& ZINGALES, 2001, p. 6), ${ }^{22}$ whereas the U.S. ratio was equal to 0.02 (a low-end value) (DYCK \& ZINGALES, 2001, p. 45; DIMITROV \& JAIN, 2006).

Companies can also choose to keep the dual class structure if they believe this is a value enhancing strategy, instead of value destroying, as suggested by part of the literature (see section 2.1). Indeed, there is inconsistent literature on the effect of dual class on corporate value (MIKKELSON \& PARTCH, 1994; DIMITROV \& JAIN, 2006; HOWELL, 2001). ${ }^{23}$ Generally, dual class IPOs outperform single class IPOs if the reputation of incumbent management is high and the company operates 
in an industry in which the difference in intrinsic values between the long-term and short-term projects available is relevant (CHEMMANUR \& JIAO, 2006, p. 7). Conversely, single class IPOs outperform dual class IPOs if the reputation of incumbent management is low and the firm operates in an industry which the difference in intrinsic values between long-term and short-term projects is not relevant (CHEMMANUR \& JIAO, 2006, p. 7).

Dual class structures can sometimes increase the market value of a company if, in case of a takeover, both incumbent and rival enjoy significant private benefits of control, and the party with high private benefits also has high security benefits. ${ }^{24}$ In this case, minority shareholders are better off with the unbundling of cash flow rights and voting rights because the winning party in a takeover has also to pay for the expected private benefits of control (GROSSMAN AND HART, 1988). Although this hypothesis is theoretically consistent, in practice there have been too few successful takeovers of dual class companies (see section 1.1 for details) to make this argument practical and relevant.

Moreover, there is empirical evidence from stock returns showing that shareholders are not harmed and actually earn significant abnormal returns following dual class recapitalizations (DIMITROV \& JAIN, 2006, p. 29). This study shows that dual class companies, on average, outperformed the matching portfolios by $23.11 \%$ in the four-year period following the announcements (DIMITROV \& JAIN, 2006, p. 29). The study suggests that the source of gains in shareholder value is profitable future growth, since it finds that dual class firms grow significantly faster than their competitors (DIMITROV \& JAIN, 2006, p. 30). The conclusion is that managers adopt dual class structures to take advantage of anticipated valuable growth opportunities without losing control and that such structure is beneficial to shareholders, as they can accept restrictions of their voting rights to maximize their wealth (DIMITROV \& JAIN, 2006, p. 30). Hence, large managerial voting control without equivalent cash flow rights, may be desirable in some circumstances.

Developing the argument of benefits to shareholders accruing from a dual class structure, it could also be argued that shares with none or restricted voting power usually receive larger dividends and thus can maximize investor wealth in a portfolio context. Moreover, since these shares tend to have more liquidity then the superior voting shares (which is true both in Brazil and the U.S.), they might be more suitable in composing a diversified portfolio. Additionally, particularly in the case of Brazil, an extensive compensatory regulation protecting preferred (non-voting) stockholders (see section 1.4 for details) increases the attractiveness of holding such shares.

Especially in the American context, the elimination of dual class structures can be viewed as a trend arising in the aftermath of the corporate governance scandals (e.g., Enron). Hence, since anything that can potentially increase managerial entrenchment becomes problematic, dual class structures became a major target, but not necessarily 
because the structure is problematic in itself. Indeed, empirical evidence suggests that dual class recapitalizations are unlikely to be motivated by entrenchment, because companies that promote dual class recapitalizations are characterized by concentrated ownership even before the adoption of the structure (CHEMMANUR \& JIAO, 2006 , p. 8). Nevertheless, the question of whether there should be a regulatory response against dual class structures remains unanswered.

In Brazil, the problem of managerial entrenchment is rarer due to the controlling shareholder structure. Despite the clear trend towards unification verified in section 2.2, the dual class structure still plays a major role in the way corporate ownership is organized in the country, due to a tradition of family businesses. On the one hand, the quest for liquidity can induce companies to list in the Novo Mercado segment, but on the other this trend can also be offset by legal protections provided to preferred stocks. Finally, there are certain regulatory requirements in the infrastructure business operated by the private sector (such as energy) and banking business 25 that mandate the figure of a controller shareholder. In concessions, for example, a change of control of the concessionaire needs to be previously approved by the public authority (Federal Law 8,987/96, article 27).

In sum, although many companies in Brazil and the U.S. have eliminated the dual class structure, a substantial number of Brazilian companies and a persistent share of American firms still prefer the dual class structure over the single class - one share one vote - paradigm. Some of the reasons why this happens were debated in this section.

\section{Conclusion}

Dual class structure is a complex strategy for corporate ownership. Despite the extensive literature on the topic, much controversy remains and companies still insist on maintaining the structure in spite of all the criticism.

This paper analyzed how two different corporate ownership settings - concentrated in Brazil and dispersed in the U.S. - perceive dual class structures as a strategic ownership structure. It discussed how dual class structures make sense when founders or management need to retain control while accessing the equity markets for financing as well as a takeover defense. The paper also indicated the main strategies for implementing a dual class structure, such as "dividend sweetener" transactions, time phase voting plans, spin-offs, issuance of stock dividends, follow on issuances and IPOs.

Following this assessment, there was an overview of the regulatory approach provided by each of the countries. A brief history of the origins of the dual class structure was outlined up to the current treatment given to these structures by both the Brazilian and the American exchanges. While the U.S. opted for a uniform policy for all exchanges, Brazil adopted a regulatory dual strategy in which the Novo Mercado 
listing segment was designed to attract new entrants wishing to voluntarily commit to higher standards of corporate governance.

This paper further presented empirical evidence of the dual class structure scenario in each country. Brazil had $74 \%$ of the listed companies using dual class shares as of 2007 and a legal framework allowing two types of stocks - preferred shares with no voting rights and common shares with one vote per share - and prohibiting multiple voting stocks. In the U.S., a much smaller comparative fraction of companies adopted the dual class structure - only 7.4\% as of 2007 - and the structure was designed in more sophisticated ways due to the possibility of multiple voting shares (in an IPO).

This paper followed by analyzing the unification process that both countries underwent. It reviewed the main criticisms formulated against dual class structures, such as the aggravation of agency problems, the risk of shareholder exploitation, the negative impact on institutional investor participation, potential problems with incompetent heirs, the absence of incentives to change in difficult times, the negative impact on the firm's value and the feature of being an effective antitakeover mechanism.

Afterwards, the paper presented empirical evidence of the unification process both in Brazil and in the U.S., with details on the determinants and implications of the change. In Brazil, a significant number of companies unified their shares in order to be listed in the Novo Mercado segment and increase share liquidity. The same quest for liquidity was also the major reason justifying the elimination of dual class structures in the U.S. Nevertheless, while in Brazil the majority shareholder kept control of the firm with reduced voting power after unification, in the U.S., $40 \%$ of the blockholders exited the company within three years after unification. There is some evidence of firm value increase in both countries and significant growth of institutional investors' participation in American firms.

Lastly, this paper discussed some of the reasons why certain companies may still prefer dual class structures to single class ones, despite all the criticism aimed at the segregation of cash flow and voting rights. Among the arguments developed were (i) the fact that one size does not fit all and that a circumstantial context could increase the attractiveness of dual class structures (e.g., the 1980s in the U.S. with the boom in takeovers); (ii) suggestions that dual class structures might not trigger many of the agency problems indicated, since a large majority of insiders with control also hold the majority of cash flow rights; (iii) the possibility that dual class companies operate in "equilibrium"; (iv) the alternative to perceive dual class structures as an intermediate level in the firm life cycle; (v) the presence of countervailing efficiency benefits that offset the agency costs associated with the dual class structure; (vi) the rent-protection theory, which suggests that controllers with large private benefits do not wish to give up such prerogatives; (vii) that dual class structures might be value enhancing strategy; and (viii) that dual class structures usually pay higher dividends and might be better for portfolio diversification. 
Even though some of the arguments are more suitable to a particular context, generally they apply both to Brazil and the U.S. Perhaps the dual class structure is not as problematic as it is perceived.

: ARTIGO APROVADO (19/02/2014) : RECEBIDO EM 08/07/2012

NOTAS

* Gabriela M. Engler Pinto is a Brazilian lawyer who specializes in the legal and regulatory aspects regarding the participation of the private sector in infrastructure. She received her master degree from Columbia Law School (LL.M., James Kent Scholar) and graduated from the Pontifical Catholic University of São Paulo, Brazil (J.D., with honors). She wishes to thank Professor Harvey J. Goldschmid and Professor Ira M. Millstein for their encouragement and guidance while attending their Corporation in Modern Society seminar at Columbia Law School.

1 The expression "Brazilian firms" is used to refer to companies listed on the Brazilian exchange (BM\&FBovespa), and not necessarily firms with Brazilian origin.

2 The expression "American firms" is used to refer to companies listed in the American exchanges (NYSE, AMEX and NASDAQ), and not necessarily firms with American origin.

3 Google, Inc., March 24, 2009 Form DEF 14A, via Edgar.

4 Moreover, Bermuda's law allows companies to have golden shares, which can be used as an effective method to hold control with a small equity stake. In Brazil, golden shares can only be held the Government.

5 The Securities Act of 1933 allocated regulatory authority under the Act to the Federal Trade Commission (FTC). The Securities Exchange Act of 1934 created the Securities and Exchange Commission and transferred to it the powers originally granted to the FTC. 15 U.S.C. § 78d (1988).

6 An example of that was the Ford Motor Company. The Ford family kept $40 \%$ of the voting power by holding a class of superior voting shares. This allowed the family to go public while retaining control with only $5.1 \%$ equity (HOWELL, 2009, p. 4).

7 Business Roundtable v. S.E.C., United States Court of Appeals, District of Columbia Circuit, June 12, 1990905, F.2d 406, 284 U.S.App.D.C. 301.

8 See Section 313.00 of the NYSE Listed Company Manual for the full text.

9 For a interesting history of the Brazilian capital market development before the 1950s, see A. Musacchio, Laws vs. Contracts: Legal Origins, Shareholder Protections, and Ownership Concentration in Brazil, 1890-1950 (2008), available at http://ssrn.com/abstract=1086450.

10 Comissão de Valores Mobiliários, História do Mercado de Capitais do Brasil, available at http://www.portaldoinvestidor.gov.br/Acad\%C3\%AAmico/EntendendooMercadodeValoresMobili\%C3\%A1 rios/Hist $\%$ C3\%B3riadoMercadodeCapitaisdoBrasil/tabid/94/Default.aspx. 
11 In Brazil, corporate law is manly a matter of federal regulation, except for certain tax aspects.

12 Bolsa de Valores de São Paulo, http://pt.wikipedia.org/wiki/Bolsa_de_Valores_de_S\%C3\%A3o_Paulo.

13 The Bovespa Mais segment restricts listed companies from publicly trading non-voting shares although companies are not prohibited from having the dual class structure.

14 Among the Novo Mercado listing requirements are: (i) no preferred stocks; (ii) mandatory tag along at 100\% of the share price; (iii) mandatory arbitration clause for corporate disputes; (iv) minimum of 5 directors with a 2 year-unified term, 20\% of whom must be independent; (v) mandatory tender offer at "economic value" in case of delisting; (vi) financial statements in accordance with U.S. GAAP or IFRS; (vii) minimum free float of $25 \%$ of total equity; (viii) disclosure of material related-party contracts; (ix) disclosure of monthly equity ownership and trading by controlling shareholders, directors and officers; and (x) public offerings to use mechanisms favoring capital dispersion.

15 Agency problems were initially discussed in the work of Jensen et al. (1976).

16 SEC rule 14a-11 provided shareholders with a mandatory right of proxy access where the shareholder or group of shareholders, owned at least 3\% of the company's securities for at least three years. There was also an amendment to the existing SEC rule 14a-8, permitting shareholders to include proposals related to proxy access in the company's proxy statement. Almost immediately upon being adopted, SEC rule 14a-11 was challenged in court. The SEC then voluntarily stayed the implementation of both rules pending resolution of this challenge, which came on July 22, 2011, when the U.S. Court of Appeals for the D.C. Circuit vacated SEC rule 14a-11. Although the court's decision was only directed at SEC rule 14a-11, it raised questions as to whether the amendment to SEC rule $14 \mathrm{a}-8$ also had been undermined. On September 2011, the Chairman of the SEC issued a statement indicating that, while the SEC would not appeal the court's decision about SEC rule 14a-11, it would proceed with implementing new SEC rule $14 \mathrm{a}-8$.

17 Data from the BM\&FBovespa website, available at http://www.bmfbovespa.com.br/cias-listadas/consultas/ ipos-recentes/ipos-recentes.aspx?idioma $=$ pt-br.

18 Out of 33 unification transactions analyzed between 2000 and 2008, only two companies adopted a dispersed ownership structure.

19 The IBOVESPA is composed of a theoretical portfolio with the stocks that accounts for $80 \%$ of the volume traded in the last 12 months and that are traded on at least on $80 \%$ of the trading days. It is revised quarterly, in order to keep it representative of the volume traded and on average the components of IBOVESPA represent $70 \%$ of all the stock value traded.

20 DeAngelo \& DeAngelo (1985) were the first to suggest that the non-pecuniary private benefits of control may be high in media-related firms and hence may induce founders to establish a dual class structure.

21 The authors also find that in countries which controlling shareholders are common, such controllers often maintain control while retaining substantially less than a majority of the cash flow rights; this is done through the use of stock pyramids, cross-holdings, and dual-class stock.

22 A different study found this ratio to be equal to 0.23 . See Nenova (2000).

23 Howell (2001) results show no significant change in firm value and conflicting results about operating performance after the unification. These results show no evidence of a recovery in value or performance by the elimination of any private benefits of control.

24 The authors refer to security benefits as the total market value of the corporation's securities.

25 The only Brazilian bank listed in Novo Mercado is Banco do Brasil, a public owned bank, in which the Brazilian Federal Government holds more than $50 \%$ of the shares. 


\section{REFERÊNCIAS BIBLIOGRÁFICAS}

ALCHIAN, A. \& DEMSETZ, H. (1972) Production, Information Costs and Economic Organization, American Economic Review V. 62, 777-795.

AMOAKO-ADU, B. \& SMITH, B. F. (2001) Dual class firms: capitalization, ownership structure and recapitalization back into single class, Journal of Banking and Finance V. 25, 1083-111.

ANDRAdE G., MITCHEll, M. \& STAFFORD, E. (2001) New Evidence and Perspectives on Mergers, The Journal of Economic Perspectives V. 15, 103-120.

BEBCHUK, L. A. (1999a) A rent-protection theory of corporate ownership and control, NBER Working Paper No. 7203, Cambridge, Mass.: National Bureau of Economic Research.

BEBCHUK, L. A., KRAAKMN, R. \& TRIANTIS, G. (1999) Stock pyramids, cross-ownership and dual class equity: the mechanisms and agency costs of separating control form cash-flow rights. NBER Working Paper n. 6951. Harvard Law School Discussion Paper n. 249.

BLOCK, S. (1991) AMEX files plan for holders' votes on classes of stock, Wall Street Journal, June 13.

BOONE, A. \& HAROLD MULHERIN J. (2007) How firms are sold?, The Journal of Finance V. 62, 847-875.

BORTOLON, P. M. \& LEAL, R. P. C. (2009) Determinantes e Consequências das Operações de Unificação de Ações no Brasil, available at http://virtualbib.fgv.br/ocs/index.php/ebf/9EBF/paper/view/658.

CHEMmanUR, T. J. \& JIAO, Y. (2006) Dual Class IPOs, Share Recapitalizations, and Unifications: A Theoretical Analysis, available at http://ssrn.com/abstract_id=925236.

COMISSÃO DE VALORES MOBILIÁRIOS, História do Mercado de Capitais do Brasil, available at http://www.portaldoinvestidor.gov.br/Acad\%C3\%AAmico/EntendendooMercadodeValoresMobili\%C3\%A1rios /Hist\%C3\%B3riadoMercadodeCapitaisdoBrasil/tabid/94/Default.aspx.

DEANGELO, H. \& DEANGELO, L. (1985) Managerial ownership of voting rights: A study of public corporations with dual classes of common stock, Journal of Financial Economics V. 14, 33-69.

DEMSETZ, H. \& LEHN, K. (1985) The structure of corporate ownership: causes and consequences, The Journal of Political Economy V. 93, 1155.

DIMITROV, V. \& JAIN, P. C. (2006) Recapitalization of one class of common stock into dual-class: Growth and long-run stock returns, Journal of Corporate Finance V. 12, 342-366.

DYCK, A. \& ZINGALES L. (2001) Private Benefits of Control: An International Comparison, available at http://ideas.repec.org/p/nbr/nberwo/8711.html

GILSON, R. J., HANSMANN, H. \& PARGENDlER, M. (2010) Regulatory Dualism as a Development Strategy: Corporate Reform in Brazil, the U.S., and the EU, Stanford Law and Economics Olin Working Paper No. 390; Columbia Law and Economics Working Paper No. 368; Yale Law \& Economics Research Paper No. 399; ECGI Law Working Paper No. 149/2010; Rock Center for Corporate Governance at Stanford University Working Paper No. 80 .

GILSON, R.J. (1987) Evaluating Dual Class Common Stock: The Relevance of Substitutes, Virginia Law Review V. 73, 807-844.

GOMPERS, P. A. \& METRICK, A. (2008) Extreme Governance: An Analysis of Dual-Class Firms in the United States, available at: http://ssrn.com/abstract $=562511$.

GORGA, E. (2008) Changing the Paradigm of Stock Ownership: From Concentrated Towards Dispersed Ownership? Evidence from Brazil and Consequences for Emerging Countries, $3^{\text {rd }}$ Annual Conference on Empirical Legal Studies Papers. GROSSMAN, S. J. \& HART, O. (1988) One share-one vote and the market for corporate control, Journal of Financial Economics V. 20, 175-202.

HARRIS ,M. \& RAVIV, A. (1988) Control contests and capital structure, Journal of Financial Economics V. 20, 55-86. HOWELL, J. W. (2001) The Value of Blockholder Liquidity and the Decision to Unify Share Classes, available at: http://ssrn.com/abstract $=1571760$.

HOWELL, J. W. (2009) Essays on the U.S. Dual-Class Share Structure, A Dissertation Submitted to the Graduate Faculty of The University of Georgia in Partial Fulfillment of the Requirements for the Degree of Doctor of Philosophy, Athens, Georgia, available at www.terry.uga.edu/finance/docs/howell_dual_class_share.pdf. JARRELL, G.A. \& POULSEN, A.B. (1988) Dual-Class Recapitalizations as Antitakeover Mechanisms: The Recent Evidence, Journal of Financial Economics V. 20, 2.

JENSEN, M.C., \& MECKLING, W.H. (11976) Theory of the Firm: Managerial Behavior, Agency Costs and Ownership Structure, Journal of Financial Economics V. 3, No. 4, 305-360.

KHANNA, T. \& PALEPU, K. (1999) Emerging market business groups, foreign investors, and corporate governance, NBER Working Paper No. 6955, Cambridge, Mass.: National Bureau of Economic Research.

LA PORTA, R., LOPEZ-DE-SILANES, F. \& SHLEIFER, A. (1999) Corporate Ownership Around The World, Journal of Finance V. 54, 471 . 
LAMY FILHO, A. \& PEDREIRA, J. L. B. (1995) A lei das S.A.: pressupostos-elaboração, $2^{\text {nd }}$ edition, v.1. Rio de Janeiro: Renovar.

LI, K., ORTIZ-MOLINA, H. \& ZHAO, X. (2008) Do Shareholder Rights Affect Institutional Investment Decisions? Evidence from Dual-Class Firms, Financial Management V. 37.

MAIA, B. (2012) Na Contramão?, Capital Aberto, April, No. 104, year 9.

MASUlis, R. W., WANG, C. \& XIE F. (2008) Agency Problems at Dual-Class Companies, Finance Working Paper No. 209/2008, available at http://ssrn.com/abstract_id=1080361.

MIKKELSON, W. H. \& PARTCH, M. M. (1994) The consequences of unbundling managers' voting rights and equity claims, Journal of Corporate Finance V. 1, 175-199.

NENOVA T. (2000) The Value of Corporate Votes and Control Benefits: A Cross-Country Analysis, mimeograph, Harvard University, available at http: / / papers.ssrn.com/sol3/papers.cfm?abstract_id=237809

PAJUSTE, A. (2005) Determinants and consequences of the unification of dual-class shares, Working Paper Series $n^{\circ} 465$, European Central Bank.

PINTO JUNIOR, M. E. (2011) Unificação de Ações:Abordagem Jurídica e Econômica, (unpublished working paper, available from the author).

REGAlADO, A. \& LUCCHETTI, A. (2007) Brazil Exchange Strikes While It's Hot, The Wall Street Journal, October 25 , at $\mathrm{C} 1$.

SAITO, R. (2003) Determinants of the Differential Pricing between Voting and Non-Voting Shares in Brazil, Brazilian Review of Econometrics. Rio de Janeiro V. 23, No. 1, 77-109.

SANTANA, M. H.; ARARAT, M.; ALEXANDRU, P.; YURTOGLU, B. B. \& CUNHA, M. R. (2008) Novo Mercado and Its Followers: Case Studies in Corporate Governance Reform, Global Corporate Governance Forum Focus 5. SELIGMAN J. (1986) Equal protection in shareholder voting rights: The one common share, one vote controversy, George Washington Law Review V. 54, 687-725.

STATE BOARD OF ADMINISTRATION (SBA), (2010) Corporate Governance Report, Dual-Class Shares Does Management Really Need Such Protection? available at www. sbafla.com/fsb/LinkClick. aspx?fileticket...tabid=732. STEVENS W.H. (1926) Stockholders' voting rights and the centralization of voting control, The Quarterly Journal of Economics V. 40, 353-392.

VILLALONGA, B. \& AMIT, R. (2006) How do family ownership, control and management affect firm value?, Journal of Financial Economics V. 80, 385-417.

22, No. 8, 3047-3091. (2009) How are U.S. Family Firms Controlled?, Review of Financial Studies, V. 